\section{PREDVIDLJIVI PUTEVI}

Milan Marinković, dipl.inž.građ.

Univerzitet u Novom Sadu, Fakultet tehničkih nauka, Departman za građevinarstvo i geodeziju, Novi Sad, milan.marinkovic@uns.ac.rs

Prof. dr Tomaž Tollazzi, dipl.inž.građ.

Univerzitet u Mariboru, Fakultet za građevinarstvo, saobraćajno inženjerstvo i arhitekturu, Maribor, tomaz.tollazzi@um.si

Doc. dr Bojan Matić, dipl.inž.građ.

Univerzitet u Novom Sadu, Fakultet tehničkih nauka, Departman za građevinarstvo i geodeziju, Novi Sad, bojanm@uns.ac.rs

Prof. dr Igor Jokanović, dipl.inž.građ.

Univerzitet u Novom Sadu, Građevinski fakultet, Subotica, jokanovici@gf.uns.ac.rs

Doc. dr Stanislav Jovanović, dipl.inž.građ.

Univerzitet u Novom Sadu, Fakultet tehničkih nauka, Departman za građevinarstvo i geodeziju, Novi Sad, stasha@uns.ac.rs

Stručni rad

Sažetak: Pojam predvidljivih puteva podrazumijeva kategorizaciju puteva $i$ očekivanja od učesnika u saobraćaju na osnovu primijenjenih elemenata. Cilj uvođenja elemenata predvidljivih puteva jeste povećanje bezbjednosti. Rezultati različitih studija su pokazali uticaj postojanja $i$ dimenzija pojedinih elemenata puta na broj saobraćajnih nezgoda. U radu su prikazani elementi koncepta predvidljivih puteva $i$ uticaj svakog od njih na bezbjednost. Zbog težnje ka povećanju stepena bezbjednosti u toku prethodnih godina je počelo primjenjivanje pojedinih elemenata koncepta predvidljivih puteva u Novom Sadu i u radu su prikazani određeni primjeri.

Ključne riječi:bezbjednost, elementi puteva, klasifikacija, razumijevanje, predvidljivost, ponašanje, očekivanje

\section{SELF-EXPLAINING ROADS}

\section{Milan Marinković, Ph.D, CE}

University of Novi Sad, Faculty of Technical Sciences, Department for Civil Engineering and Geodesy, Novi Sad, milan.marinkovic@uns.ac.rs

Tomaž Tollazzi, Ph.D, CE

University of Maribor, Faculty of Civil Engineering, Transportation Engineering and Architecture, Maribor, tomaz.tollazzi@um.si

\section{Bojan Matić, Ph.D, CE}

University of Novi Sad, Faculty of Technical Sciences, Department for Civil Engineering and Geodesy, Novi Sad, bojanm@uns.ac.rs

Igor Jokanović, Ph.D, CE

University of Novi Sad, Faculty of Civil Engineering, Subotica, jokanovici@gf.uns.ac.rs

Stanislav Jovanović, Ph.D, CE

University of Novi Sad, Faculty of Technical Sciences, Department for Civil Engineering and Geodesy, Novi Sad, stasha@uns.ac.rs

Professional paper Abstract: The notion of self-explaining roads implies the categorization of roads and expectations from participants in traffic based on the applied elements. The goal of introducing elements of self-explaining roads is to increase safety.
The results of different studies have shown the influence of the existence and dimensions of certain elements of the road on the number of traffic accidents. The paper presents elements of the concept of self-explaining roads and the impact of each of them on safety. Due to the tendency to increase the level of safety in the previous years, the application of certain elements of the concept of selfexplaining roads in Novi Sad has begun and some examples are presented.

Keywords: safety, roads elements, classification, understanding, predictability, behavior, expectation

\section{DEFINICIJA PREDVIDLJIVIH PUTEVA}

Na prvi pogled pojam „Self-Explaining Road“ (SER) je teško razumljiv. Naime, postavlja se osnovno pitanje kako put uopšte može biti samoobjašnjavajući. Ideja da će vozač tokom vožnje sam uočiti odnosno razumjeti šta se od njega traži i da će „slika puta“ u njemu automatski izazvati saobraćajno sigurnu reakciju, na prvi pogled se čini vrlo pojednostavljena. Ali SER se temelji baš na psihologiji, sa posebnim naglaskom na unutrašnjim misaonim procesima. Polazište je dakle u očekivanjima vozača -saobraćajno sigurna interakcija između očekivanja vozača i okoline puta čini saobraćajno sigurnu okolinu.

Pojava pojma „predvidljivi putevi“ se vezuje za 1992. godinu i za Holandiju [1]. Autori koji su prvi put upotrijebili pojam objavili su rad pod nazivom Begrijpelijkheidvandeweg što u doslovnom prevodu sa holandskog znači „razumljivi putevi“. Autori su se odlučili za naziv predvidljivi putevi (SER) kako bi što bolje i razumljivije opisali pojam. Karakteristična terminologija predvidljivih puteva obuhvata pojmove kao što su kategorizacija, percepcija i očekivanje, harmonizovana standardizacija, razumljivo projektovanje puteva, uočljivost, psihološko umirenje saobraćaja, doslijednost i izvodljivost.

Kategorizacija puteva je bazirana na teoriji prototipova čija je osnova tvrdnja da korisnici puta razvijaju prototipsku detekciju tipova puteva u slučaju kada je fizički izgled okoline puta homogen i fizički različit od okoline drugih tipova puteva. Nepravilna kategorizacija puteva je opasna jer uzrokuje pogrešna očekivanja korisnika puteva [2].

\section{KONCEPT PREDVIDLJIVIH PUTEVA}

Zemlje u kojima je koncept najviše zastupljen su: Holandija, Danska, Velika Britanija, Njemačka, Francuska, Italija, Australija i Novi Zeland. Predvidljivi putevi povezuju kategorizaciju putne mreže i očekivanja korisnika puteva. 
Saobraćajna okolina bi trebalo da utiče na pravilna očekivanja od korisnika puteva, uzimajući u obzir prisustvo i ponašanje drugih učesnika u saobraćaju, kao i vlastito ponašanje. Karakteristični sistem kategorizacije puteva bi trebalo da ispunjava sljedeće uslove:

- svaka kategorija treba da se sastoji od jedinstvenih putnih elemenata (homogenost $u$ okviru jedne kategorije i različitost u odnosu na sve druge kategorije);

- svaka kategorija treba da zahtijeva jedinstveno ponašanje za specifičnu kategoriju (homogenost u okviru jedne kategorije i različitost u odnosu na sve druge kategorije);

- jedinstveno ponašanje iskazano na putevima treba da bude povezano sa jedinstvenim putnim elementom;

- geometrijsko oblikovanje (pravci, krivine, prelazne krivine) i vizuelni utisak geometrije treba da budu jedinstveni za pojedine kategorije puta;

- treba izabrati kategoriju puta koja je bitna za ponašanje učesnika;

- ista kategorija puta treba da povezuje dionice puta koje su psihološki prikazane kao cjelina;

- ne bi trebalo biti naglog prelaza sa jedne kategorije na drugu kategoriju puta;

- kod prelaza iz jedne na drugu kategoriju puta promjena bi trebalo da bude jasno označena i prepoznatljiva;

- kada postoje dvije kategorije puteva, svaka bi trebalo ne samo da pripada kategoriji, već i da definiše zahtijevano ponašanje za taj tip puta;

- oznaka kategorije i dodatne oznake bi trebalo da budu vidljive i noću i danju;

- projektovanje puteva bi trebalo da smanji razlike u brzinama, kao i razlike u načinu kretanja;

- elementi puta, oznake i znakovi treba da ispunjavaju standardne kriterijume vidljivosti;

- sistemi upravljanja saobraćajem bi trebalo da budu povezani sa specijalnim kategorijama puta.

U skladu sa prethodno navedenim, na Slici 1. je prikazano upoređenje osnovnih postavki kategorizacije puteva prema klasičnom pristupu i prema principima održivosti. Pri tome je značajno naglasiti da principi održivosti istovremeno obuhvataju funkcionalnu klasifikaciju i elemente predvidljivosti. Slika 2. ilustruje funkcionalnu kategorizaciju putne mreže putem koje je moguće odrediti i stepen prilagođavanja zahtijevanoj predvidljivosti.

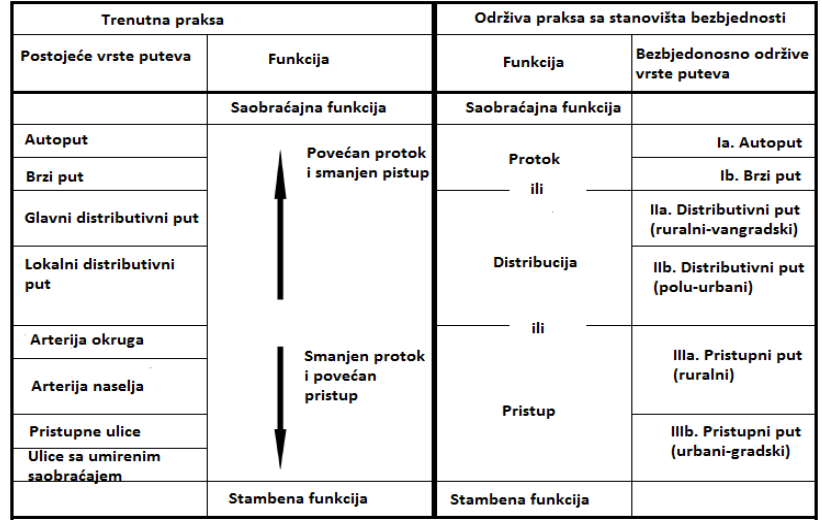

Slika 1. Trenutna praksa kategorizacije puteva i podjela prema principu održive bezbjednosti [3]

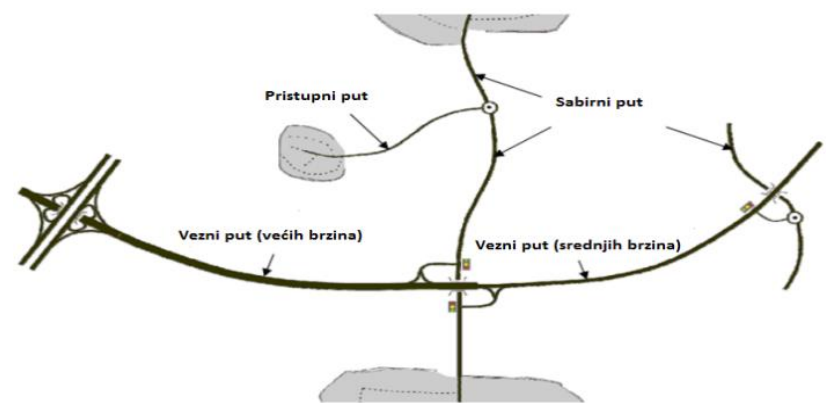

Slika 2. Grafički prikaz predvidljivih puteva [4]

Uspostavljanje mreže predvidljivih puteva sa ciljem smanjenja nenamjernih udesa mora biti povezano sa sistematskim i interdisciplinarnim mjerenjima obuhvatajući infrastrukturu i obrazovanje korisnika (Slika 3).

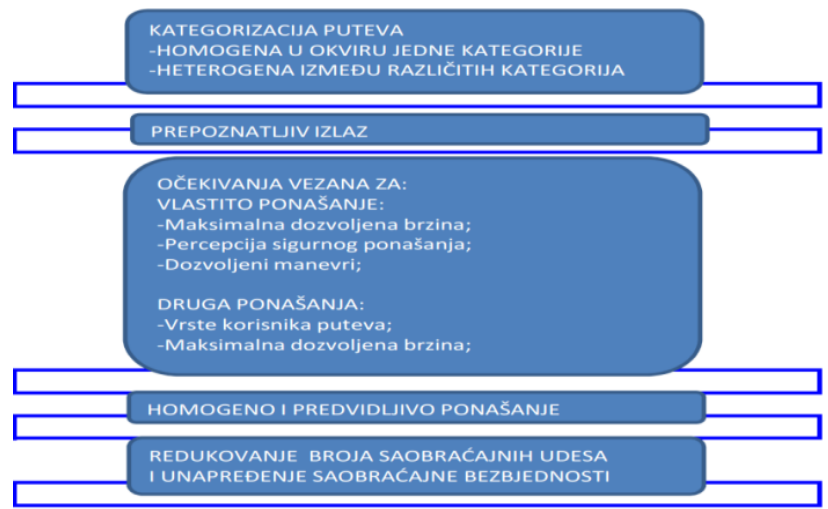

Slika 3. Procedura za uspostavljanje mreže predvidljivih puteva [5]

\section{ELEMENTI PREDVIDLJIVIH PUTEVA}

\subsection{Efekti karakteristika puta na ponašanje vozača}

Od 50-tih godina prošlog vijeka broj vozila se, u pojedinim zemljama svijeta, povećao 10 puta. Za razliku od tog trenda, broj udesa i poginulih se nije previše uvećao (Slika 4). Međutim, taj broj je i dalje jako velik. 


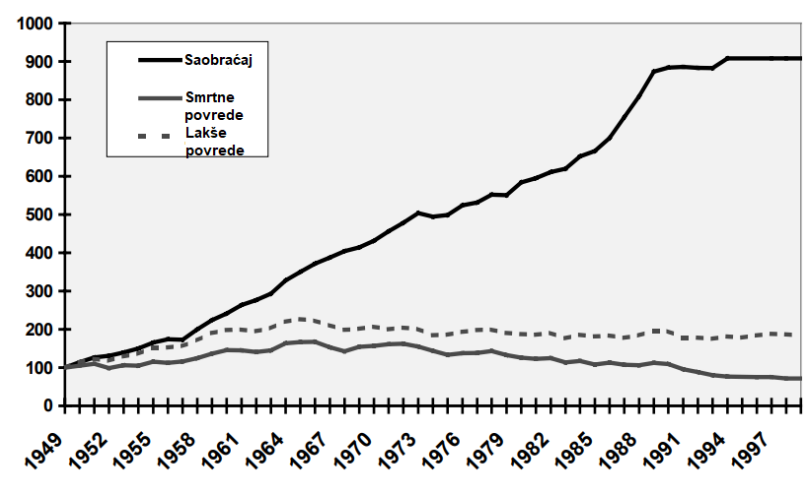

Slika 4. Broj vozila, poginulih i povrijeđenih [6]

U Tabeli 1. je prikazana analiza broja povrijeđenih i poginulih u saobraćajnim udesima u tri zemlje, gdje je moguće sagledati određene odnose u vezi sa ponašanjem vozača u saobraćaju.

Tabela 1. Analiza broja stanovnika i saobraćajnih parametara [7]

\begin{tabular}{|l|c|c|c|}
\hline \multicolumn{1}{|c|}{ pokazatelj } & Srbija & Poljska & Mađarska \\
\hline broj stanovnika & 7.882 .795 & 38.644 .000 & 9.000 .000 \\
\hline broj motornih vozila & 1.666 .347 & 13.616 .000 & 2.840 .187 \\
\hline broj privatnih vozila & 1.445 .057 & 9.673 .000 & 2.302 .000 \\
\hline stepen motorizacije & 185 & 220 & 268 \\
\hline broj udesa & 48.650 & 57.331 & 17.493 \\
\hline broj poginulih & 1.648 & 6.294 & 1.064 \\
\hline broj povrijeđenih & 16.547 & 71.638 & 16.429 \\
\hline $\begin{array}{l}\text { broj poginulih na } \\
\text { milion stanovnika }\end{array}$ & 134 & 168 & 118 \\
\hline poginuli/100 udesa & 22 & 11 & 6.1 \\
\hline $\begin{array}{l}\text { poginuli/10.000 } \\
\text { privatnih vozača }\end{array}$ & 7,3 & 6,5 & 4,5 \\
\hline $\begin{array}{l}\text { udesi na milion } \\
\text { stanovnika }\end{array}$ & 6.219 & 1.484 & 1.944 \\
\hline $\begin{array}{l}\text { udesi/1.000 } \\
\text { motornih vozila }\end{array}$ & 29,2 & 4,2 & 6,2 \\
\hline
\end{tabular}

Karakteristike puta utiču na ponašanje vozača što se ogleda kroz brzinu vožnje, broj preticanja i broj grešaka, kao i bočnu poziciju. Uticaj karakteristika puta na pojedine parametre saobraćaja je prikazan u Tabeli 2.
Tabela 2. Uticaj pojedinih karakteristika puta na ponašanje vozača [8]

\begin{tabular}{|c|c|c|c|c|}
\hline & karakteristika & $\begin{array}{c}\text { prosječna } \\
\text { brzina }\end{array}$ & $\begin{array}{c}\text { broj } \\
\text { preticanja } \\
\text { i \% } \\
\text { prekršaja }\end{array}$ & $\begin{array}{l}\text { bočna } \\
\text { pozicija }\end{array}$ \\
\hline \multirow{2}{*}{$\begin{array}{l}\text { tip zastora } \\
\text { puta }\end{array}$} & grublja površina (kaldrma & - & & \\
\hline & obnova asfalta & + & & \\
\hline \multirow[t]{2}{*}{ separator } & veće fizičke & & - & \\
\hline & duple osovinske linije & - & - & \\
\hline \multirow[t]{4}{*}{ oznake u } & bez oznaka & & & $r$ \\
\hline & dodatak osovinske linije & + & & a \\
\hline & ivična linija & $+/-$ & & \\
\hline & osovinska linija & - & & $r$ \\
\hline \multirow[t]{3}{*}{ širina trake } & oznaka u bočnom smjeru & - & & \\
\hline & Širina trake $<3 \mathrm{~m}$ & - & & \\
\hline & širina trake $>3,75 \mathrm{~m}+$ & + & & \\
\hline \multicolumn{2}{|l|}{ reflektori } & $+/{ }_{-}^{* * *}$ & & $a / r$ \\
\hline \multirow{2}{*}{$\begin{array}{l}\text { (neobavezne) } \\
\text { biciklističke }\end{array}$} & gradsko područje & 0 & & $r$ \\
\hline & vangradsko područje & 0 & & $a$ \\
\hline \multicolumn{2}{|l|}{ građevine } & $-^{*}$ & & \\
\hline \multirow{4}{*}{$\begin{array}{l}\text { vegetacija } \\
\text { pored puta }\end{array}$} & kontinualna & + & & $r^{* *}$ \\
\hline & raširena & - & & \\
\hline & van krivina & $+* * /-$ & & a \\
\hline & u krivinama & - & & \\
\hline \multicolumn{2}{|c|}{ prepreke/parkirana vozila } & $-{ }^{*}$ & & \\
\hline \multirow{2}{*}{$\begin{array}{l}\text { prisustvo } \\
\text { drugih }\end{array}$} & spor saobraćaj & - & & \\
\hline & dolazeća vozila & & & $r$ \\
\hline \multicolumn{5}{|c|}{\begin{tabular}{|ll} 
a & prema osi puta \\
$r$ & prema strani puta \\
$*$ & što je kraće rastojanje između građevine/prepreke i puta to je manja \\
& brzina \\
$*$ & osim desne krivine \\
$* * \star$ & pravci i lijeve krivine sporije, desne krivine brže
\end{tabular}} \\
\hline
\end{tabular}

\subsection{Obilježavanje u podužnom pravcu}

Granice kolovozne trake koje pružaju informaciju o širini trake i pravcu pružanja puta mogu biti označene iscrtavanjem centralnih oznaka, ivičnih oznaka, kao i središnjih linija. Granične linije povećavaju sposobnost vozača da ostane u okviru trake (posebno u krivinama), s tim što vozači uglavnom mogu voziti brže kada je označavanje na višem nivou (Slike 5 i 6). Uz oznake vozači mogu lakše ocijeniti sopstveno kretanje i upravljivost vozilom na osnovu sposobnosti da zadrže poziciju u traci određenom brzinom, bez razmatranja da li se mogu zaustaviti i izbjeći neočekivani događaj. Ovaj problem je posebno izražen noću.
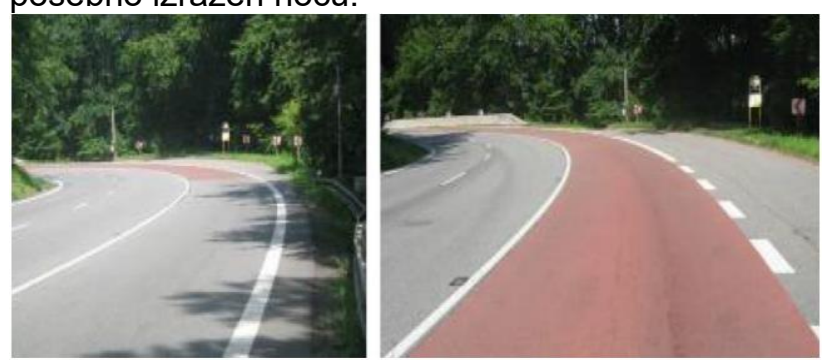
Slika 5. Način bojenja i obilježavanja kolovozne površine [9]

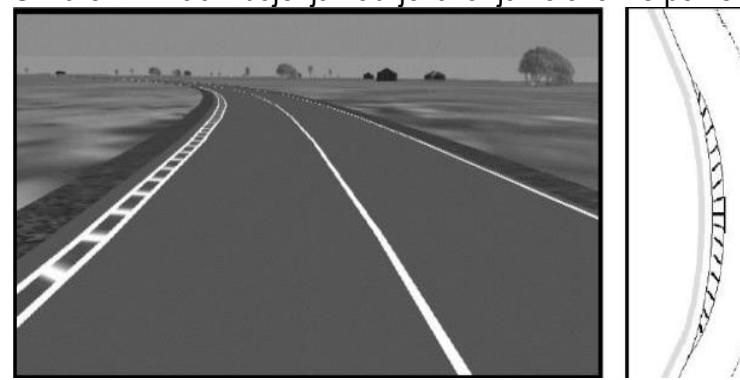

Slika 6. Noćni izgled podužnih oznaka sa šrafurom na unutrašnjoj strani krivine [10]

Važno je naglasiti da postavljanje oznaka po sredini i na ivicama kolovoza ne dovodi uvijek do povećanja brzine. Ako primijenimo rešetkaste oznake na ivicama da bi smanjili spoznajnu širinu trake tada brzina opada [11].

\subsection{Razdvajanje smjerova vožnje}

Prilikom prolaska puteva državnog značaja kroz naseljena mjesta manje i/ili srednje veličine potrebno je pristupiti pojedinim korekcijama. Prilikom prolaska puta kroz naselje, posebna pažnja se posvjećuje regulisanju puta i prostora za kretanje vozila, prisiljavajući vozača da smanji brzinu, te poveća oprez u vožnji. Najpogodnija za tu namjenu je primjena razdjelnog ostrva ili kružnog toka. Razdjelna ostrva su posljednjih godina znatno unaprijeđena što se tiče bezbjednosti, ali su u pojedinim slučajevima ili premala ili neadekvatno projektovana. Suviše mala ostrva (Slika 7) su neefikasna pa prilikom projektovanja treba provjeriti provoznost mjerodavnog vozila.
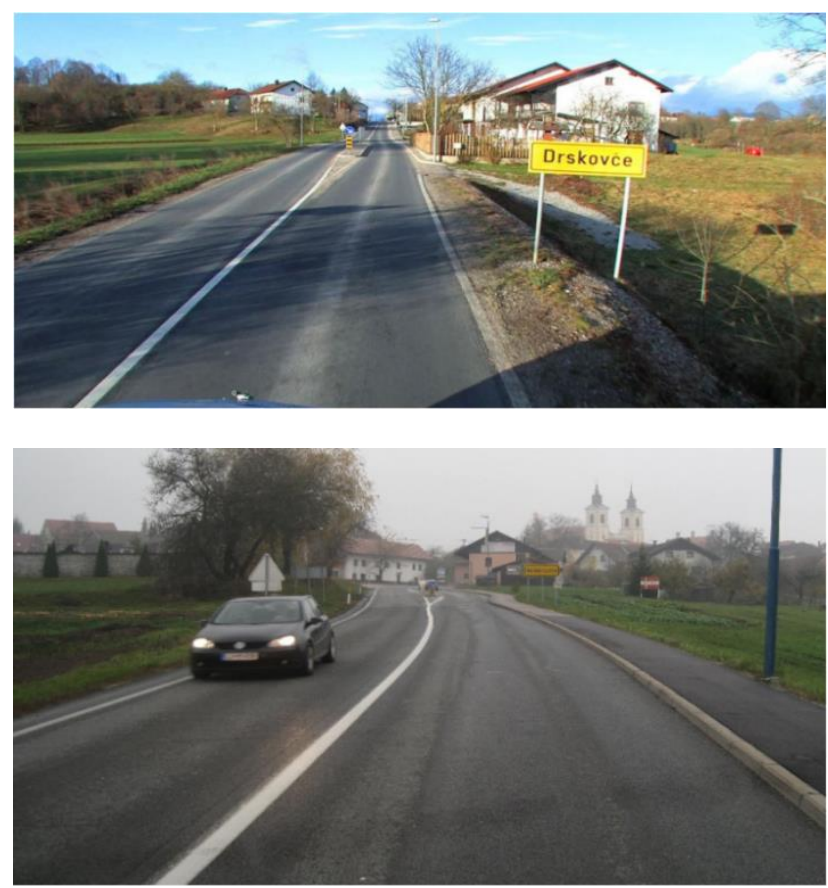

Slika 7. Primjeri premalog razdjelnog ostrva [12]
Kao posljedica, potrebno je proširenje kolovoza što kod manjih ostrva dovodi do toga da osobna vozila prolaze većom brzinom. Pored toga, ostrva su manje primjetna što može da poveća broj udesa. Razdjelno ostrvo treba da bude što je moguće veće tako da osa kolovoza usmjeri vozača i na taj način smanji brzinu. Kada je ostrvo vidljivo sa dovoljne daljine tada vozač može prilagoditi brzinu u skladu sa sposobnošću reakcije (Slika 8.).

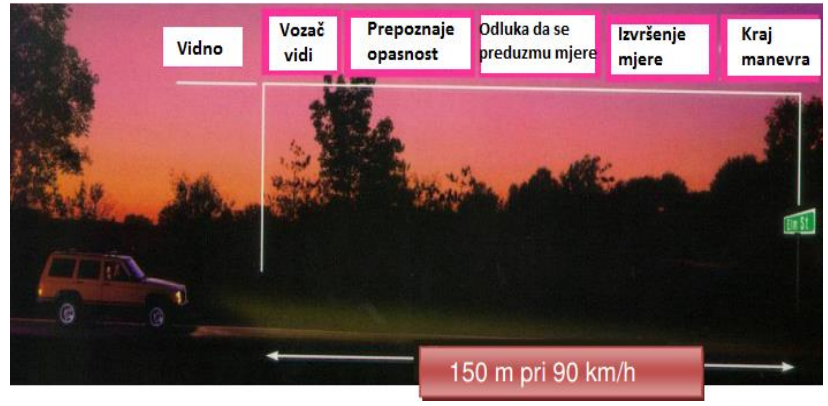

Slika 8. Potrebna dužina da se vozilo zaustavi na vrijeme [12]

Preporučuje se i zatravljivanje ostrva ili sadnja grmlja i manjih stabala (Slike 9 i 10) kako bi se povećala njegova vidljivost. Ostrvo mora biti pravilno locirano (neposredno iza znaka koji označava naselje).

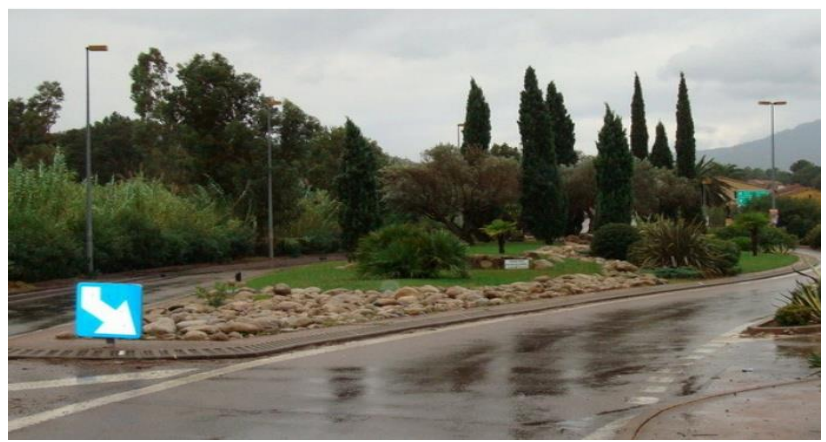

Slika 9. Primjer dobro izvedenog ostrva sa zelenilom [12]

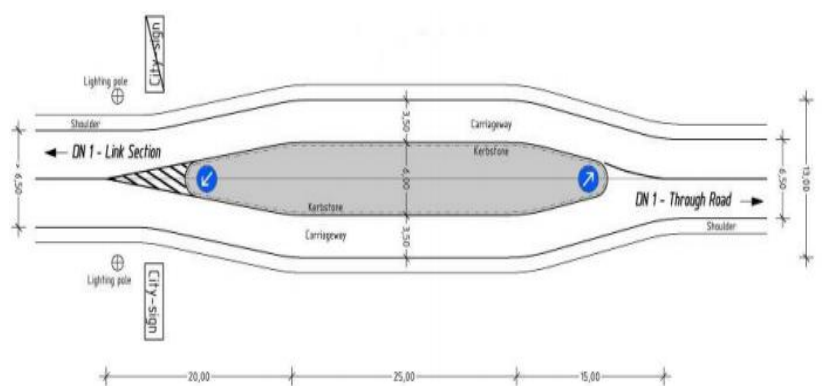

Slika 10. Pravilno projektovano ostrvo [12]

\section{3. Širina traka}

Širina trake utiče na ponašanje vozača, posebno na brzinu vožnje, bočnu poziciju i preticanje [13]. Rađene su studije koje su za cilj imale da utvrde uticaj širine trake na ponašanje vozača. 
Rezultati jednog istraživanja [14] su pokazali da su za širine kolovoza manje od $6,0 \mathrm{~m}$ brzine značajno manje. Tokom istraživanja je pokušano uspostavljanje klase širine puta, ali za podjele veće od 6,0 m (6,0-7,0 m i 7,0-8,0 m) nije bilo prevelike razlike $\mathrm{u}$ brzinama (manje od $2 \mathrm{~km} / \mathrm{h}$ ). Rezultati istraživanja su pokazali $\mathrm{i}$ da je na putevima sa „utvrđenom“ bankinom (bankina od asfalta) (ukupne širine preko 11,0 m) ostvarena veća brzina (od 8 do $13 \mathrm{~km} / \mathrm{h}$ ) u odnosu na puteve bez utvrđene bankine od asfalta.

Sužavanje trake sa 3,6 m na optičku širinu manju od $3,0 \mathrm{~m}$ dovodi do smanjenja brzine za $2 \mathrm{~km} / \mathrm{h}$ [15]. Polja za usmjeravanje saobraćaja mogu dovesti do smanjenja brzine i do $6,0 \mathrm{~km} / \mathrm{h}$ zbog vizuelne interpretacije širine trake.

Studije su pokazale da su brzine značajno manje kada su vozne trake uže od $3.0 \mathrm{~m}$ u odnosu na šire trake [16]. Uže trake ne ostavljaju dovoljno prostora za korekciju odluke nakon grešaka u vožnji i to negativno utiče na bezbjednost saobraćaja.

\subsection{Biciklistička i pješačka infrastruktura}

Razlikuju se četiri tipa biciklističkih površina (Slike 1116):

- biciklistička staza;

- neobavezna biciklistička staza;

- traka za bicikliste i/li mopede;

- servisni put.

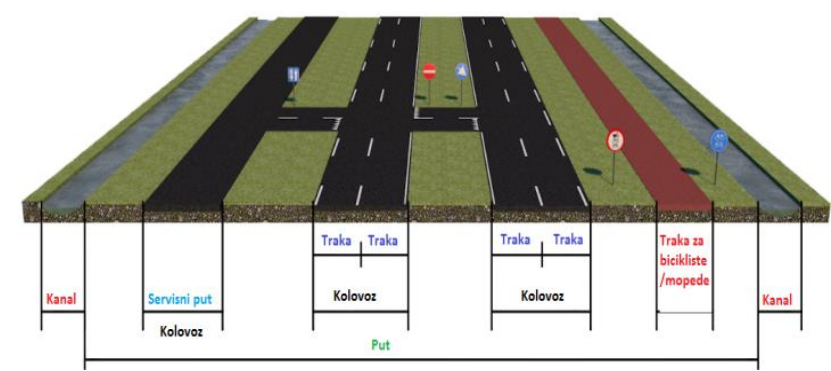

Slika 11. Prikaz traka u poprečnom profilu puta [17]

Biciklističke staze i neobavezne staze su sastavni dio kolovoza i označene su isprekidanim ili kontinualnim podužnim oznakama. Biciklističke i/ili mopedske trake i servisni putevi su paralelni putu i koriste se jedino na distributivnim putevima, kako u gradskim, tako i u vangradskim uslovima. Biciklisti dijele svoju infrastrukturu sa ostalim sporim motorizovanim vidovima saobraćaja, kao što je moped, i sa poljoprivrednim vozilima.

Biciklističke staze i neobavezne staze mogu biti obojene nekim bojama (npr. crvena), a obavezno su označene piktogramom bicikliste. To znači da ostale vrste vozila mogu koristiti ovaj dio kolovoza jedino ako žele da se parkiraju sa desne strane biciklističke staze.
Neobavezne biciklističke staze imaju niži status. Biciklisti nisu u obavezi da in koriste, a ove trake mogu koristiti i drugi vidovi saobraćaja.

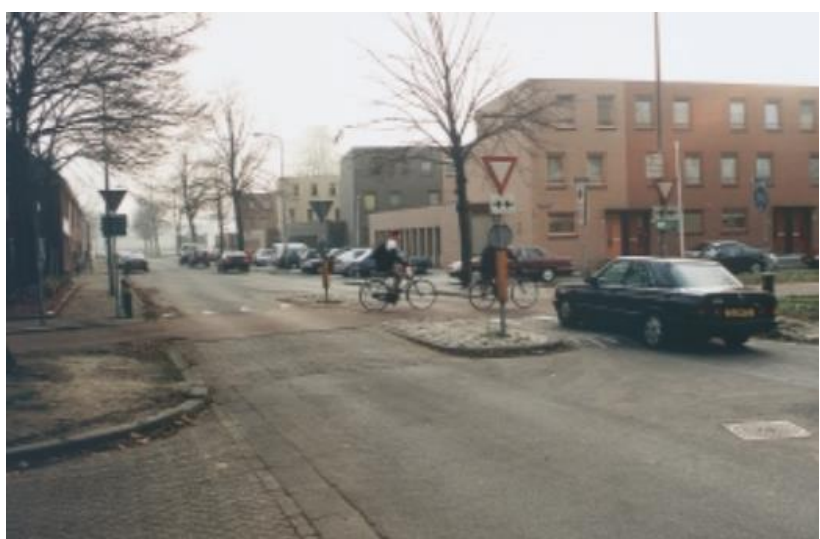

Slika 12. Raskrsnica sa biciklističkom trakom kao glavnom trakom [18]

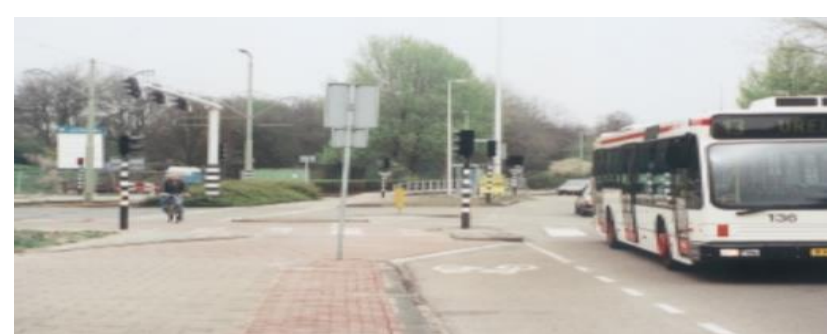

Slika 13. Raskrsnice sa razdvojenim biciklističkim i mopedskim trakama [18]

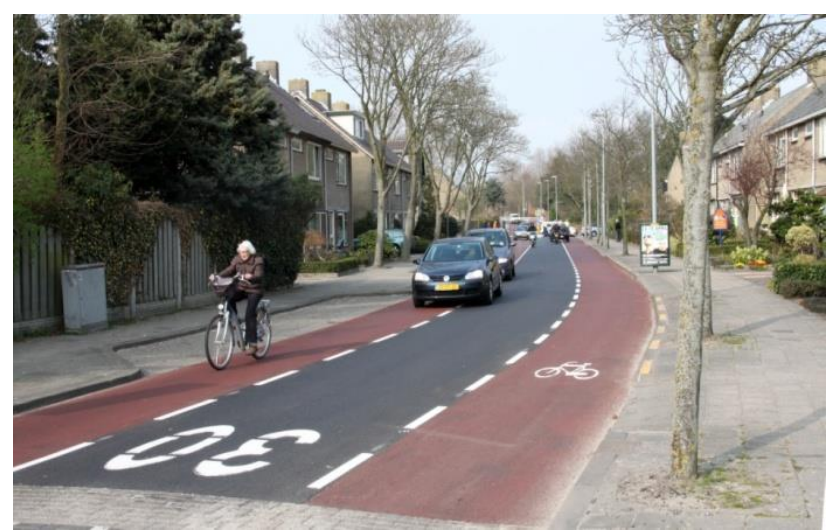

Slika 14. Biciklističke staze obilježene drugom bojom [19]
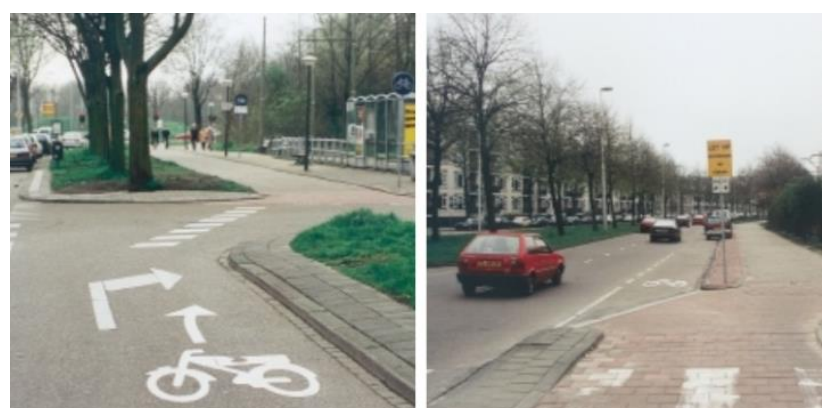

Slika 15. Znakovi i oznake za moped na putu [18] 


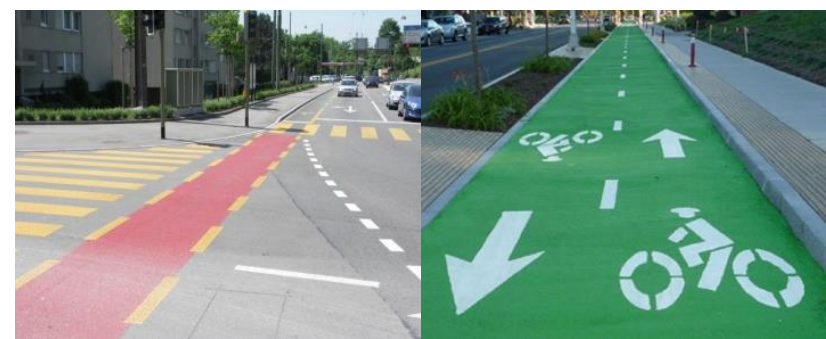

Slika 16. Obilježavanje biciklističkih staza u raskrsnici i van raskrsnice $[20,21]$

\subsection{Površina (zastor) puta i stepen hrapavosti}

Vrsta i (ne)ravnost zastora puta imaju uticaj na ponašanje vozača. Gruba površina puta (zastori od blokova ili lomljenog kamena), koja je česta na manje važnim i manje opterećenim putevima, dovodi do smanjenja brzine $u$ odnosu na asfaltne zastore. Sporija vožnja je rezultat smanjenja komfora vožnje zbog veće buke i zbog vibracija, a grube površine kolovoza mogu dovesti i do otežane kontrole vozila. Kvalitet površine puta ima jako veliki uticaj na brzinu vožnje. Schnüll i dr. [22] su istraživali uticaj obnove kolovoza u Njemačkoj (Brandenburg). Nakon analize $300 \mathrm{~km}$ vangradskih puteva i više od 4.400 udesa u studiji prije-poslije, otkrili su različita povećanja u ozbiljnosti udesa (+43\% ozbiljnijih povreda), kao i porast udesa sa samo jednim učesnikom (+50\%) i izlijetanja sa puta (+77\%). Kao razlog za promjenu nakon obnove kolovoza, otkrili su različita povećanja u prosječnoj brzini, koja nisu u skladu sa nivelacijom puta.

U odnosu na unapređenje saobraćajne bezbjednosti, preporuka je da se kolovoz ne popravlja bez procjene da li ima potrebe za mjerama kao što su smanjenje brzine, postavljanje znakova ili označavanje suženja puta.

\subsection{Karakteristike ivičnih oznaka i bankine}

Kallberg [23] je proučavao efekte ivičnih oznaka na ponašanje vozača i sudare (Slika 17). Proučavajući podatke prije i poslije na putevima za dozvoljene brzine od $80 \mathrm{~km} / \mathrm{h}$ i $100 \mathrm{~km} / \mathrm{h}$ sa osovinskim i ivičnim oznakama pod različitim okolnostima kao što su noćdan, ljeto-zima, itd. ustanovio je da su vozači više pomjerali vozilo $u$ stranu (i na putevima sa ograničenjem brzine na $80 \mathrm{~km} / \mathrm{h}$ i na $100 \mathrm{~km} / \mathrm{h}$ ) i da su vozili brže na putevima projektovanim za $80 \mathrm{~km} / \mathrm{h}$. Povećanje broja sudara je primijetio na putevima projektovanim za brzine od $80 \mathrm{~km} / \mathrm{h}$, dok se broj sudara nije previše promijenio na putevima projektovanim za brzine od $100 \mathrm{~km} / \mathrm{h}$ ili je čak bio smanjen u zimskim i dnevnim uslovima. Takođe je zaključeno da je prosječna bočna pozicija bila bliže osovini.
Blaauw [24] je zaključio da ivično postavljene oznake na rastojanju od $3.5 \mathrm{~m}$ nisu previše efikasne i da bi traka trebalo da bude zaštićena sa obe strane sa oznakama na bankinama ili na ivičnjacima na rastojanju od $1.5 \mathrm{~m}$.

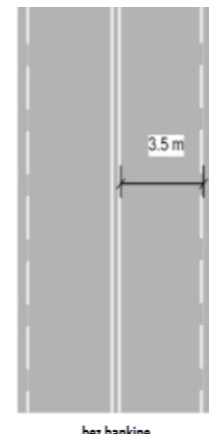

ber bankine

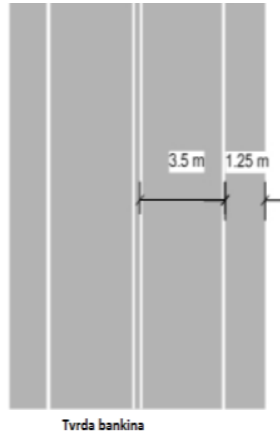

Tvrda bankina

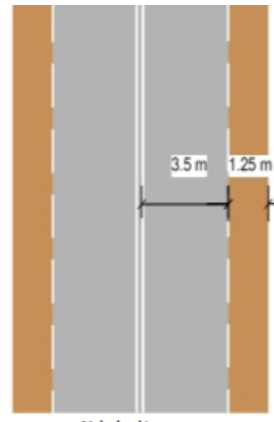

Meka bankina
Slika 17. Vrste bankina i pozicioniranje podužnih oznaka [22]

Neka istraživanja [25] su proučavala i položaj markera u krivinama i zaključeno je da su ivične oznake dale bolje rezultate. Oznake su dale rezultat i u oštrim krivinama, ali su u tim slučajevima bile dovoljne i ivične oznake. Ivične oznake su u lijevim krivinama dovele do smanjenja brzine, dok su u desnim krivinama dovele do povećanja brzine.

U Njemačkoj i Sjedinjenim Američkim Državama se „tvrda“ bankina (od asfalta) koristi za saobraćaj u slučajevima smanjene brzine ili za kretanje vozila javnog prevoza.

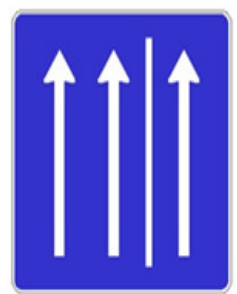

Upotreba tvrde bankine

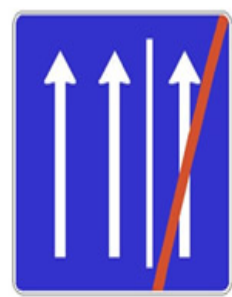

Kraj upotrebe tvrde bankine

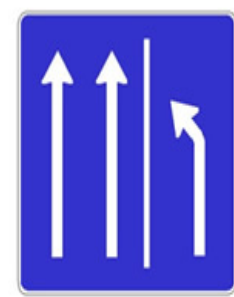

Napusti tvrdu bankinu
Slika 18. Primjer upotrebe utvrđene bankine [26]

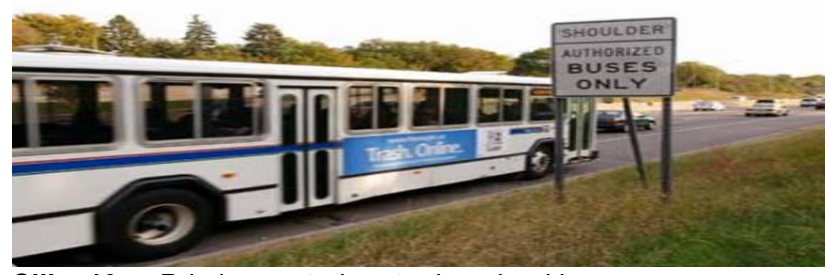

Slika 19. Primjer upotrebe utvrđene bankine samo za autobuse [27]

\subsection{Put i okolina}

Razne studije su pokazale postojanje određene veze između objekata i/ili vegetacije oko puta i ponašanja vozača. U većini studija je kao mjerodavan faktor uzimana brzina. 
U nekim studijama je proučavana i bočna pozicija Prisustvo objekata i vegetacije može uticati na odluke vozača i kretanje vozila na više načina. Najvažnije je da smanjuju vizuelni prostor, ali istovremeno smanjuju i prostor za manevrisanje.

Opšta preporuka koja proizilazi iz tih studija je da treba projektovati puteve tako da se poveća pažnja vozača. Što je veća brzina, to je dalji fokus, a vidno polje se sužava (Slike 20, 21, i 22). To znači da se pri većim brzinama može prikupiti manje informacija.

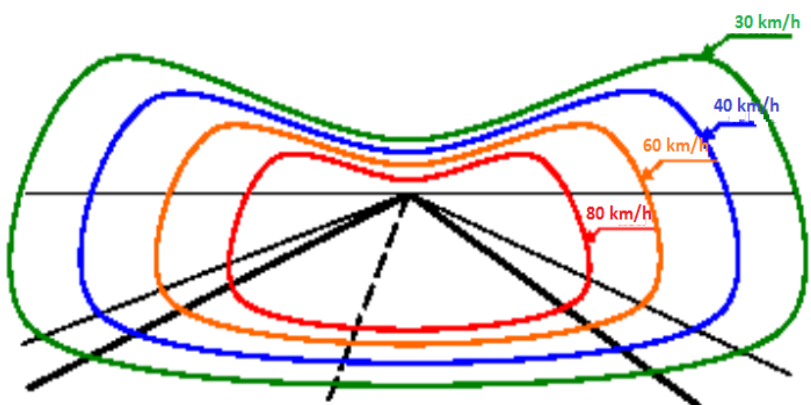

Slika 20. Obuhvat vidnog polja pri različitim brzinama [28]

Vegetacija pored puta može imati i pozitivnih i negativnih uticaja na projektovanje puteva i na bezbjednost saobraćaja (Slika 23).

U savremenom projektovanju puteva vegetacija se koristi kako bi se povećao stepen jedinstva i usklađenosti puta sa okolinom. U nekim slučajevima može se desiti i tzv. „efekat tunela“ ako krošnje preklapaju kolovoz i formiraju krov (zbog funkcije navođenja) (Slika 24). Ovaj efekat se teže ili se uopšte ne primjećuje tokom zime zbog opadanja lišća. U krivinama desne orijentacije redovi drveća dovode do smanjenja brzine, dok u krivinama lijeve orijentacije dovode do povećanja brzine.

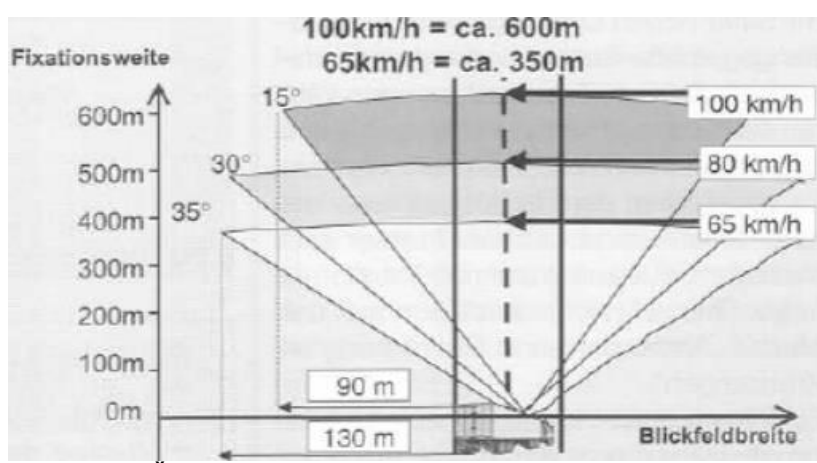

Slika 21. S Sirina vidnog polja pri različitim brzinama [29]

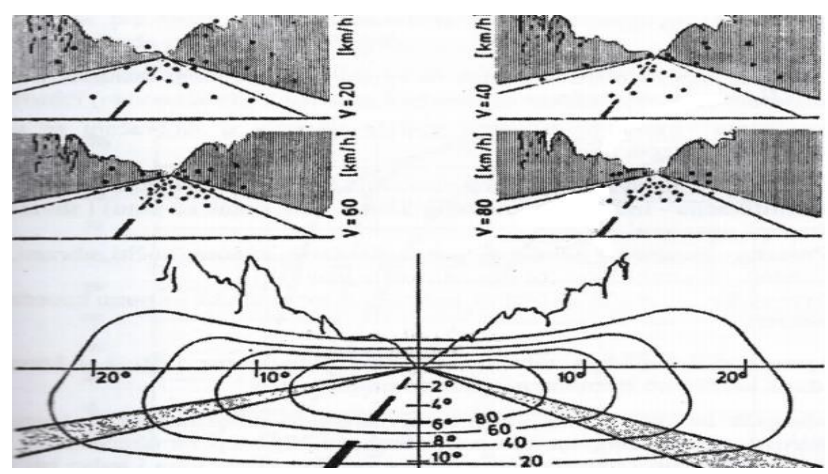

Slika 22. Obuhvat vidnog polja i zone usmjerenih vizura vozača koje se registruju pri različitim brzinama [30]

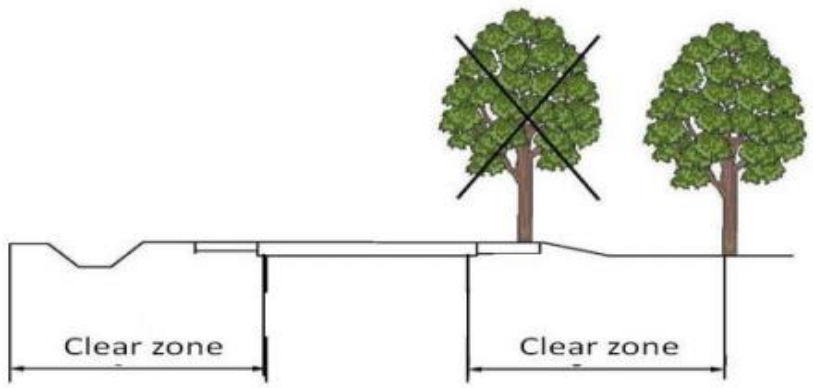

Slika 23. Položaj vegetacije u poprečnom profilu [31]

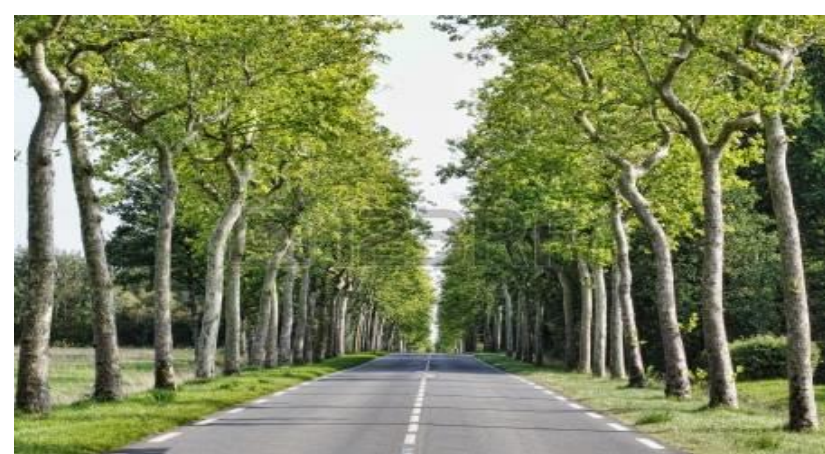

Slika 24. Položaj vegetacije u poprečnom profilu [32]

\subsection{Objekti i oprema pored puta}

Ispitivanja su pokazala da je brzina manja ukoliko se pored puta nalaze određeni objekti. Takođe, što su objekti bliži putu to je brzina manja [33, 34]. Oprema pored puta može imati različitu apsorpcionu energiju (Slika 25). Upotrebom opreme i signalizacije sa nižim stepenom apsorpcije mogu se ublažiti posljedice sudara i izlijetanja vozila.

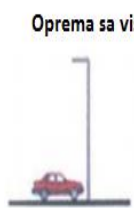

Oprema sa niskom apsorpcijonom energijom
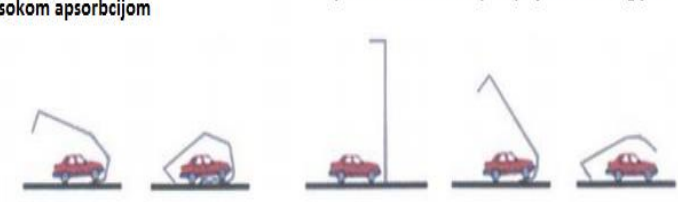

Slika 25. Stubovi javne rasvjete sa različitom energijom apsorpcije [35] 


\subsection{Raskrsnice}

Sa stanovišta saobraćajne bezbjednosti najveću mogućnost za poboljšanje daju zone površinskih raskrsnica. Razlikuju se četiri tipa raskrsnica:

- četvorokraka raskrsnica sa prioritetnim putnim pravcem;

- trokraka raskrsnica sa prioritetnim putnim pravcem;

- kružne raskrsnice;

- semaforizovane raskrsnice (na putevima van naselja nisu baš česte).

Položaj, karakteristike, vrsta raskrsnice i distribucija saobraćajnih tokova u raskrsnici imaju veliki uticaj na saobraćajnu bezbjednost. Poznato je da učestalost saobraćajnih udesa u velikoj mjeri zavisi od broja raskrsnica i ukrštaja na jedinici putne mreže. Sa porastom broja krakova u raskrsnicama raste i broj konfliktnih tačaka što negativno utiče na bezbjednost (Slika 26). Rizik od nastanka udesa raste sa porastom saobraćajnog opterećenja na raskrsnicama između sporednog i glavnog pravca.

Poželjno je, u slučajevima kada je saobraćajno opterećenje na sporednom pravcu veoma visoko, preprojektovati klasičnu površinsku raskrsnicu u raskrsnicu tipa kružnog toka (ako to uslovi lokacije dozvoljavaju i sa time ne dolazi do poremećaja propusnosti). Glavna prednost kružnog toka je u manjem broju konfliktnih tačaka što je posljedica sprječavanja ukrštanja i ograničenja uliva i izliva. Kružni tok svojim oblikom doprinosi većoj bezbjednosti [36].
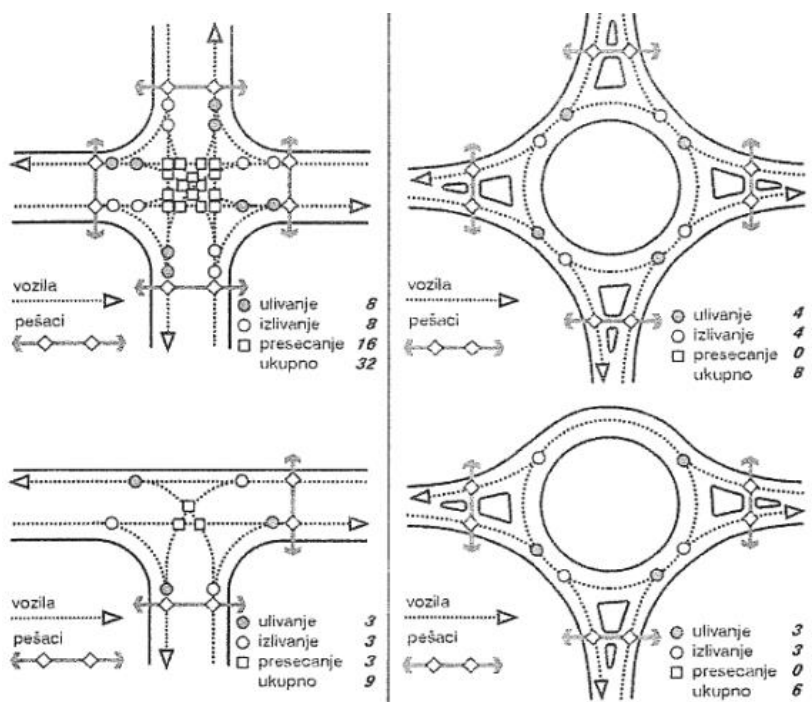

Slika 26. Raspored presječnih (konfliktnih) i ulivno-izlivnih (kolizionih) tačaka [30]

S obzirom na tip raskrsnice, najmanje bezbjedne su „zapletene“ raskrsnice, kao što su četvorokrake ili višekrake nesemaforizovane, dok su najbolje za bezbjednost kružne, semaforizovane ili trokrake raskrsnice [37].
Ključni faktor za omogućavanje višeg stepena bezbjednosti je da su raskrsnice, bez obzira na tip, razumljive, vidljive i pregledne.

Dobra vidljivost i preglednost $u$ raskrsnici u zoni pristupa istoj omogućava vozaču da se blagovremeno pripremi na sve promjene.

Za vozača na glavnom pravcu je važno da svjesno u raskrsnici očekuje vozila koja se uključuju sa sporednog pravca, dok je za vozača na sporednom pravcu važno da pravovremeno prepozna i vidi raskrsnicu, te da se zaustavi.

Dobru vidljivost i preglednost je potrebno obezbijediti kod svih raskrsnica, bilo da se one javljaju iznenada ili da se javljaju nakon dužih dionica bez raskrsnica.

Jedan od načina povećanja vidljivosti raskrsnica, ali i drugih kritičnih mjesta na putu, jeste i isticanje znakova sa fluorescentnim podlogama, kao i znakova koji se automatski aktiviraju (Slika 27).

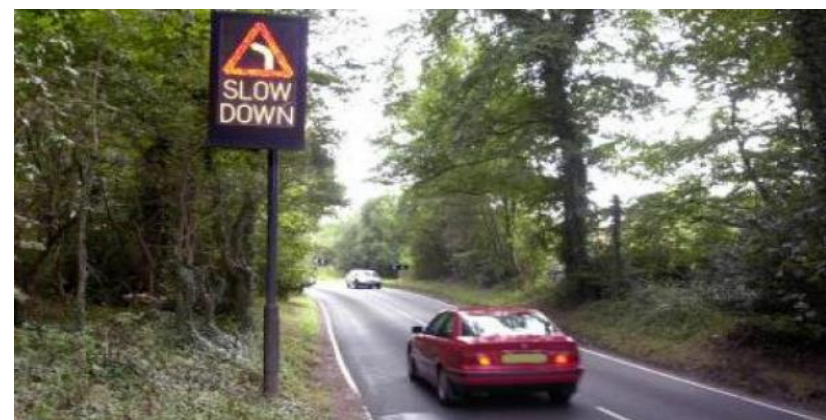

Slika 27. Znak koji upozorava na oštru krivinu [9]

Kako bi pravovremeno upozorili vozače na približavanje raskrsnicama moguće je primijeniti i:

- podužne oznake (ivične ili središnje linije);

- poprečne linije (široke poprečne crte, kose linije i oznake u obliku trouglova);

- druge oznake (koplja, šrafure, stubići, natpisi i drugi simboli) (Slika 28).

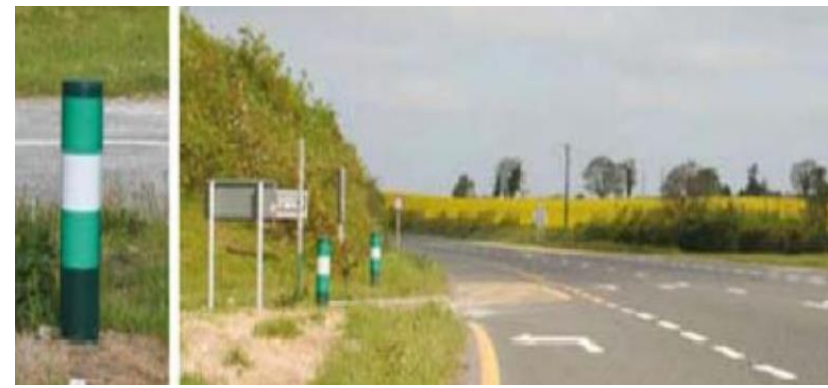

Slika 28. Znak koji naglašava priključak sporednog pravca glavnom pravcu [9] 


\subsection{Uticaj drugih korisnika puta}

Razlike se mogu uspostaviti između dva tipa korisnika puta- ostala motorna vozila i povredljivi korisnici puta. Uticaj pješaka, biciklista i vozača mopeda dovodi do smanjenja brzine kretanja motornih vozila. Osnovna motivacija za usporenje može biti ista kao i za parkirana vozila -povećanje rizika da se pješak slučajno nađe na traci. lako se različitim mjerama može uvećati stepen pažnje u zonama sa povećanim prisustvom pješaka i/ili biciklista (Slika 29), njihov efekat je lokalnog karaktera (ne samo vezano za mjesto, već i za doba dana i za vremenske uslove).

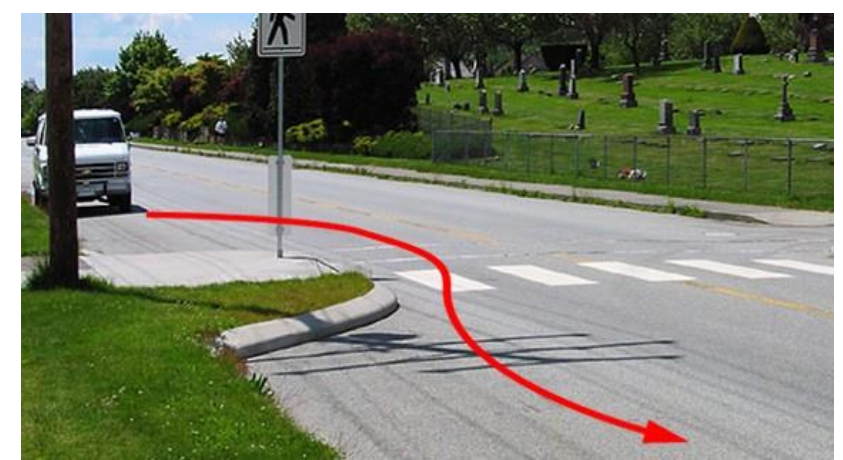

Slika 29. S Smanjena dužina pješačkog prelaza [38]

Prisustvo drugih korisnika puta bi trebalo da utiče na izbor brzine vozila tako da vozači u obzir uzmu i ponašanje svih objekata koji se kreću (a ne samo postojanje stacionarnih elemenata iz okoline puta). Za očekivati je da vozači uspore vozilo usljed prisustva korisnika puta kao što su pješaci ili biciklisti jer što je saobraćaj zagušeniji to je uticaj raspoloživog prostora na izbor brzine veći. U slobodnim tokovima, brzina svakog vozača može biti zavisna od brzine ostalih vozila i drugih učesnika u saobraćaju.

\section{PRIMJENA ELEMENATA KONCEPTA PREDVIDLJIVIH PUTEVA U NOVOM SADU}

Usljed želje da se poveća stepen bezbjednosti tokom prethodnih godina je počelo primjenjivanje pojedinih elemenata koncepta predvidljivih puteva u Novom Sadu (iako u skromnom obimu). Do sada su primijenjeni elementi obilježavanja biciklističkih staza.

Za njihovo obilježavanje je korišćena crvena termoplastika (Slike 30 i 31). Obilježene su biciklističke staze u jednom kružnom toku (Bulevar patrijarha Pavla), u dvije raskrsnice (Bulevar oslobođenjaBulevar cara Lazara (Slika 30) i Bulevar oslobođenjaJevrejska ulica) i biciklističke staze u dijelovima dvije ulice (Kisačka ulica (Slika 31) i ulica Maksima Gorkog).

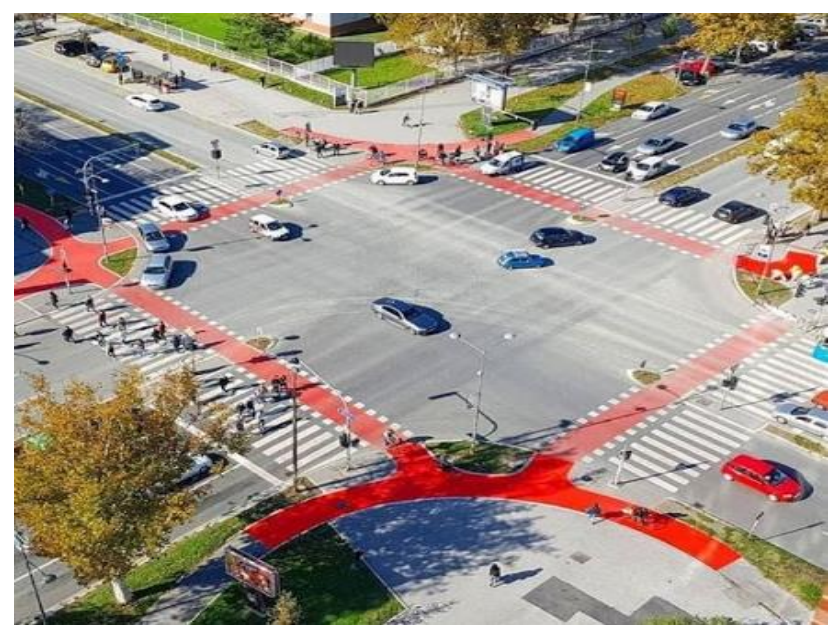

Slika 30. Raskrsnica ulica Bulevar oslobođenja i Bulevar cara Lazara [39]

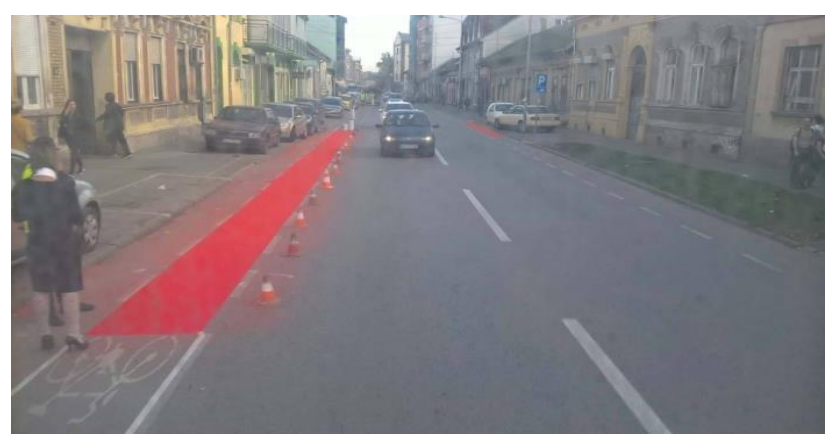

Slika 31. Biciklistička staza u Kisačkoj ulici [40]

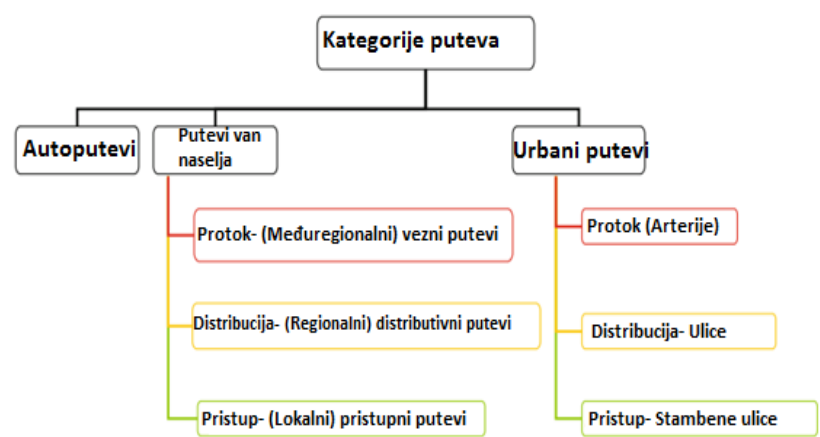

Slika 32. Predložena kategorizacija puteva prema konceptu predvidljivih puteva [4]

\section{ZAKLJUČAK}

Predvidljivi putevi imaju za cilj da povećaju bezbjednost saobraćaja. Pojam predvidljivih puteva podrazumijeva posebnu pažnju prilikom kategorizacije puteva (Slika 32) i njihovog projektovanja sa ciljem povećanja bezbjednosti u saobraćaju.

Korigovanjem geometrije puteva smanjuje se broj udesa na putevima. Istraživanjima je utvrđeno da postoje tri vrste koncepta predvidljivih puteva. 
Koncept predvidljivih puteva je dosada najuspješnije primijenjen u Holandiji i Njemačkoj dok su koncepti u većini drugih zemalja u početnoj fazi realizacije (uglavnom priprema i testiranje). Koncepti u svim zemljama imaju određenih sličnosti, ali i razlika. Bez obzira na razlike, predvidljivi putevi bi trebalo da zadovoljavaju sljedeće uslove:

- da budu prepoznatljivi- Ovo pravilo se ne može uvijek poštovati. Usljed različitog obima saobraćaja putevi iste kategorije ne mogu uvijek imati isti poprečni profil pa se zato na istim kategorijama primjenjuju različiti tipovi raskrsnica;

- da se izdvajaju- Putevi različitih kategorija treba da se izdvajaju i da se razlikuju jedni od drugih;

- da budu lako razumljivi i sigurni- Korisnici puta treba da budu obaviješteni o pravilnom ponašanju praktično od strane samog puta (pomoću oznaka). Iz ovog razloga, pri projektovanju puteva je potrebno uzeti u obzir ljudski faktor.

Različitim studijama je potvrđeno da vozači, iako uočavaju specifičnosti puta, voze većom brzinom nego što je dozvoljena brzina vožnje. Ovim je potvrđeno da primjena osnovnih preporuka bez uključenja ljudskog faktora može dovesti do poboljšanja samo ako vozači poštuju pravila. Poželjno je, prilikom uvođenja koncepta, obaviti informativno-obrazovne kampanje kako bi se vozači bolje upoznali sa konceptom i novim elementima.

Koncept predvidljivih puteva je samo jedan od koraka ka povećanju bezbjednosti saobraćaja. Potrebna su i dodatna istraživanja kako unaprijediti postojeću putnu mrežu u koncept predvidljivih puteva jer su postojeći putevi dominantni po broju u odnosu na nove puteve tako da treba utvrditi što efektivnija uputstva o načinu preprojektovanja postojeće putne mreže.

\section{Zahvale}

Ovaj rad je dio istraživanja u okviru projekta „Primena novih tehnologija za projektovanje i građenje i unapređenje nastavnog procesa u građevinskom inženjerstvu“, podržan od Departmana za građevinasrstvo i geodeziju (Univerzitet u Novom Sadu, Fakultet tehničkih nauka, Novi Sad, Srbija).

\section{Literatura}

[1] Theeuwes, J., Godthelp, J. (1992). Begrijpelijkheid van de weg. IZF 1992 C-8. Instituut voor Zintuigfysiologie IZF TNO. Soesterberg (The Netherlands)

[2] Prestor, J. (2014). Predvidljive ceste. Magistarsko delo. Maribor, Univerza v Maribori, Fakulteta za gradbeništvo. (mentor Renčelj, M.): 124 str.

[3] Wegman, F., Wouters, P., SWOV Institute for Road Safety Research (2002). Road safety policy in the Netherlands: facing the future, Published in Annales des Ponts et Chaussées, nouvelle série no. 101, janviers-mars, Leidschendam, The Netherlands

[4] Matena, S., Louwerse, W., Schermers, G. (2008). Road Design and Environment-Best practice onSelf-explaining and Forgiving Roads. Project RIPCORD-ISEREST, Deliverable D3: 38 str.

[5] Prestor, J., Klemen, B., Zoltar, S., Renčelj, M., (2014). Selfexplaining roads: concept analysis and a proposal for the establishment in Slovenia. Dostupno preko:

http://www.yubs.rs/Simpozijumi/RAP_2014_Radovi/010_P restor_Self_explaining_roads_RAP_2014_Rad.pdf

(13.06.2017)

[6] Kate McMahon (2003). The similarities between modern quality and environmental management and the use of a "Zero Vision" concept in the road transport system. Safe \& Sustainble Transport

[7] Marija Rašeta Vukosavljević (2003). Safe and Sustainable Traffic in the Republic of Serbia. Safe \& Sustainble Transport

[8] SWOV (2010). SER and SER Approaches: State-of-the-art Dostupno preko:

http://web317.login-

14.hoststar.at/web/eraser/downloads/ERASER\%20WP01 \%20Deliverable.pdf (13.06.2017)

[9] Charman, S., Grayson, G., Helman, S. ( 2010). SelfExplaining Roads Literature Review and Treatment Information. ENR SR01 project SPACE Deliverable Nr. 1: 88 str.

[10] Godley, S., Fildes, B., Triggs, T., Brown, L. (1999). Perceptual Countermeasures: Experimental Research. Road Safety Research Report CR82.AustralianTransport Safety Bureau, Canberra, Australia: 69 str. Dostupno preko: http://www.monash.edu.au/miri/research/reports/atsb182. pdf (14.06.2017)

[11] Elliott, M., Baughan, C.J., Broughton, J., Chinn, B., Grayson, G.B., Knowles, J., Smith, L.R. \& Simpson H. (2003). Motorcycle Safety: A Scoping Study, TRL Report TRL 581, Crowthorne

[12] Bricelj, A., Brumec, U.(2012). Predvidljive ceste kot ključ do prometne varnosti, 11. slovenski kongres o cestah in prometu, Portorož, 24-25. oktobra. 
[13] Becher, T., Baier, M., Steinauer, B., Scheuchenpflug, R., Krüger, H-P.(2006). Berücksichtigung psychologischer Aspekte beim Entwurf von LandstraßenGrundlagenstudie, Final Report FE 02.230/2003/AGB, BASt

[14] Bakaba, J. E. (2003). Ableitung vereinfachter Modellansätze zur Geschwindigkeitsprognose auf Außerortsstraßen auf der Grundlage der verfügbaren Variablen aus der Straßendatenbank, Dissertation, Dresden, Technische Universität Dresden, Fakultät Verkehrswissenschaften, Germany

[15] Godley, S. (2000). A driving simulator investigation of perceptual countermeasures to speeding. PhD Thesis. Monash University. Victoria (Australia)

[16] Palm, I., Schmidt, G. (1999). Querschnittsbreiten einbahniger Außerortsstraßenund Verkehrssicherheit [Cross-section widths of one-lane roads outside built-up areas and traffi csafety. Federal Highway Research Institute (BASt). Bergisch Gladbach (Germany) Dostupno preko: https://www.theoryhouse.nl/car-basictheory-knowledge/ (20.06.2017)

[17] Schermers, G., van Vliet, P. (2001). Sustainable Safety in the Netherlands: Evaluation of National Road Safety Program, Netherlands

Dostupno preko: https://upload.wikimedia.org/wikipedia/commons/thumb/e/ eb/Fietsstrook_Herenweg_Oudorp.jpg/640pxFietsstrook_Herenweg_Oudorp.jpg (20.06.2017)

[18] Dostupno preko: http://john-s-allen.com/blog/wpcontent/uploads/2011/01/20090519_JM_7858.jpg (20.06.2017)

[19] Dostupno preko: http://www.transpo.com/roadshighways/materials/pavement-marking-material/colorsafe-bike-lanes (20.06.2017)

[20] Abele, L., Møller, M. (2012).The relationship between road design and driving behavior, a simulator study

[21] Kallberg, V. P. (1991). The effects of reflector posts on driving behaviour and accidents. Proceedings of the PTRC Transport, Highways and Planning 19th Summer Annual Meeting, str. 181-192.

[22] Blaauw, G.J. (1985). Vehicle guidance by delineation systems at night. Ergonomics 28(12), 1601-1615.

[23] Krammes, R. A., Tyer, K. D. (1991). Post-mounted delineators and raised pavement markers: their effect on vehicle operations at horizontal curves on two-lane rural highways. Transportation Research Record (1324), str. 59-71.;

[24] Tiemke, K., Irzik, M. (2006). Temporary Use of Hard Shoulders-Experiences and Economic Assessment. Bergisch Gladbach, Germany: Federal Highway Research Institute, Traffic Planning, Highway Design, and Safety Analyses Section, June Dostupno preko: https://ops.fhwa.dot.gov/publications/fhwahop10023/chap 3.htm (22.06.2017)
[25] Lassus, B.(2006). Contribution of the landscape, Presentation held at the symposium Roads otherwise Designing roads to induce calm driving, organised by the French General Directorate of Roads, 9th March, Paris (France)

[26] Vollpracht, H-J., Et Birth,S. (2002). Human factors in Road System design .Piarc Seminar "Management of Road Safety", Bangkok, Thailand

[27] Maletin,M. (2005). Planiranje i projektovanje saobraćajnica u gradovima, Orion art, Beograd

[28] Dostupno preko: https://us.123rf.com/450wm/johny007pan/johny007pan12 08/johny007pan120800032/14764846-road-with-freshgreen-trees-on-side.jpg?ver=6 (21.06.2017)

[29] Kerkhof, W. van de, Bérénos, M. (1989). Stedenbouwkundige factoren beïnvloeden rijsnelheid. [Urban development factors influence speed]. Verkeerskunde, 41, str. 30-33.

[30] CROW (2004). Richtlijn essentiële herkenbaarheidkenmerken van weginfrastructuur: wegwijzer voor implementatie. No. 203. CROW National Information and Technology Platform for Transport, Infrastructure and Public space. Ede (The Netherlands)

[31] Pfajfer, T., Prislan, D., Sajovic, R. (2010). ZIP drogovi cestne razsvetljave z obirom naEN 12767 - pasivna varnost nosilnih konstrukcij cestne opreme. V: 10. slovenski kongres o cestah in prometu, Portorož, 20-22. oktobra: str. 1457-1463. Dostupno preko:

[32] Tollazzi, T. (2006). Turbo-krožno krožišče. V: 8. slovenski kongres o cestah in prometu, Portorož, 25-27. oktobra: $11 \mathrm{str}$;

[33] Aarts, L., Pumberger, A., Lawton, B., Charman, S., Wijnen, W.( 2011). Road Authority Pilot and Feasibility study. ENR SRO1 project ERASER Deliverable Nr 3 and 4: str.8-19;

[34] Dostupno preko: https://media2.fdncms.com/thecoast/imager/pinchpointsor-curb-extensions-areused/u/original/4560504/pinchpoint.jpg (18.06.2017)

[35] Dostupno preko:https://docs.google.com/forms/d/e/1FAlpQLScHx68 vGOL_9cLzuFsCR7beTulOjvlaSrQ3gQpfnDUsiqvrkg/view form (10.01.2018)

[36] Dostupno preko: http://www.021.rs/story/NoviSad/Vesti/147576/FOTO-Crvene-staze-za-bicikliste-uKisackoj-ulici.htm (10.01.2018) 